\title{
黑猩ヶ蠅に於ける高率の不分離現象"
}

\author{
千 野 光 茂 \\ 京都帝國大學理學部動物學教空
}

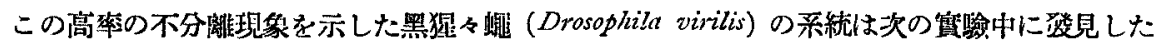

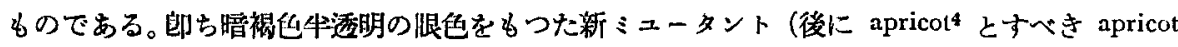
の邪四の複對ゲンなることを㶰つたもの)の雌に singed6 の雄をかけた $F_{1}$ 同志の交配から得た $\mathrm{F}_{2}$ の分離中に singed $^{6}$ となつた此一㱜があつた (1935 年 9 月 24 日の篮見)。

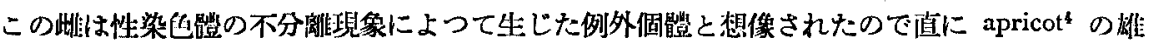

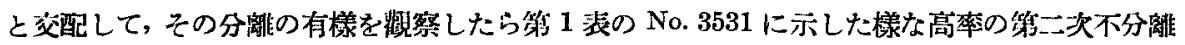

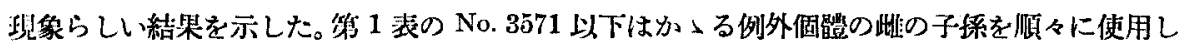
て行つた翼羷である。

第 1 表 高宰の第二次不分路現象を示寸采統の赛驗表

\begin{tabular}{|c|c|c|c|c|c|c|}
\hline 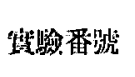 & 变 & \multicolumn{2}{|c|}{ 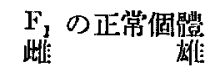 } & \multicolumn{2}{|c|}{$\begin{array}{l}\mathrm{F}_{1} \\
\text { 雉 }\end{array}$} & 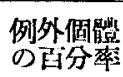 \\
\hline 3531 & $\mathrm{si}^{6} \times \mathrm{ap}^{4}$ & 74 & 49 & 8 & 6 & 10.2 \\
\hline 3571 & $\mathrm{si}^{6} \times \mathrm{v}^{3} \mathrm{mt}$ & 81 & 62 & 10 & 3 & 8.3 \\
\hline 3573 & $\mathrm{si}^{6} \times \mathrm{y}^{3}$ & 17 & 39 & 2 & 5 & 11.1 \\
\hline 3590 & $\mathrm{si}^{6} \times a \mathrm{p}^{3}$ & 30 & 24 & 2 & 3 & 8.5 \\
\hline 3602 & $\mathrm{si}^{6} \times \mathrm{we}$ & 85 & 64 & 10 & 17 & 15.2 \\
\hline 3610 & $\mathrm{si}^{6} \times \mathrm{y}^{3}$ & 61 & 58 & 1 & 2 & 2.8 \\
\hline 3611 & " & 112 & 101 & 2 & 6 & 3.6 \\
\hline 3612 & $"$ & 15 & 14 & 0 & 1 & 5.0 \\
\hline 3613 & $"$ & 108 & 79 & 1 & 0 & 0.5 \\
\hline 3614 & $"$ & 70 & 59 & 3 & 2 & 3.7 \\
\hline 3621 & $"$ & 27 & 24 & 2 & 0 & 3.8 \\
\hline 3622 & $\mathrm{si}^{6} \times \mathrm{v}^{3} \mathrm{mt}$ & 80 & 100 & 3 & 5 & 4.3 \\
\hline 3623 & " & 103 & 95 & 4 & 2 & 2.9 \\
\hline 3624 & $"$ & 85 & 90 & 0 & 2 & 1.1 \\
\hline 3625 & $"$ & 73 & 82 & 1 & 2 & 1.9 \\
\hline 3642 & $\mathrm{si}^{6} \times \mathrm{we}^{\mathrm{e}}$ & 63 & 48 & 7 & 11 & 14.0 \\
\hline 3643 & $"$ & 90 & 82 & 6 & 10 & 8.5 \\
\hline 訫 & & 1174 & 1070 & 62 & 77 & 5.8 \\
\hline
\end{tabular}

この柔䋁はその分離の狀熊から想俟して明に高率の第二次不分噰 現像を示すものと思はれた

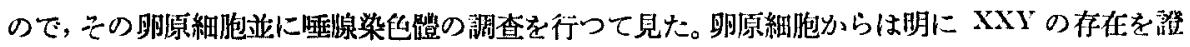

* Chino, M., A high grade Non-disjunction in Drosophila virils. (A Preliminary Note). 


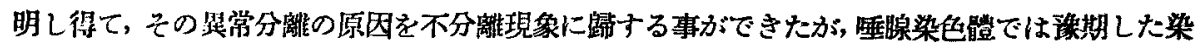
色體の逆位や啮位を證明ナることができなかつた。然しこれは使用した個體が僅少の虎につい 染色嚂異常の個體に譄遇しなかつた鹪と考へても恐らく誤はなからう。

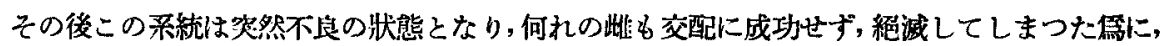
十分その原因を陮められなかつたのは誠に殘念である。

然し第 2 表の示寸樣に黑显々蠅の第二次不分離現象は極めて低率で僅に $0.5 \%$ 位の例外個趽 を出すのにすぎないがこの柔統は甚だしく高率で No. 3602 の如きは算に例外個體が $15.2 \%$ にも卖して居る。

第 2 奉 普通の第二次不分離現象の綜合結果

\begin{tabular}{|c|c|c|c|c|c|c|}
\hline \multirow{2}{*}{$\frac{\text { 慣 }}{\text { Weinstein }}$} & \multirow{2}{*}{$\frac{\text { 睮 }}{\left({ }^{\prime} 22\right)}$} & \multicolumn{2}{|c|}{$\begin{array}{l}F_{1} \text { 正常個體 } \\
\text { 雌 }\end{array}$} & \multicolumn{2}{|c|}{$\begin{array}{l}\mathrm{F}_{2} \\
\text { 此 }\end{array}$} & \multirow{2}{*}{$\frac{\begin{array}{c}\text { 例外個聙 } \\
\text { の百分率 }\end{array}}{1.3}$} \\
\hline & & 792 & 700 & 8 & 11 & \\
\hline Demerec anc & d Farrow ('30) & 1848 & 1606 & 9 & 8 & 0.5 \\
\hline Kikkawa & ('32) & 1141 & 914 & 2 & 9 & 0.5 \\
\hline Kikkawa & ('35) & 1568 & 1493 & 0 & 2 & 0.1 \\
\hline Chino & (未潑表) & 460 & 333 & 1 & 3 & 0.5 \\
\hline 合 & 䚵 & 5809 & 5046 & 20 & 33 & 0.5 \\
\hline
\end{tabular}

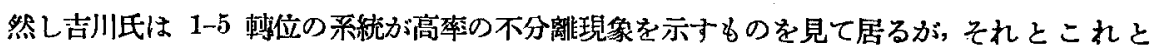
はその原因を異にするものである。然し系統の失はれた以上哚く研究する手段がないので面 の原因は不明と云ふより他はないのが借憾である。然し黑猩々蠅としては珍らしい高率の Nondisjunction である妨ら，不完圣ながらこっにこれを報告なる次第である。

本研究には服部報会金の補助金の一部を使用したからこれを特記して感謝の意を表する。

\section{猩々蠅屬に於ける性染色體の構成(豫 報)*}

\section{片山久男吉川秀男 京都帝國大學理學部動物學教室}

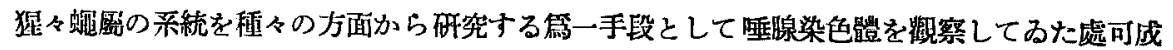
り與味の有る事實が見出された。然し立では其の中,性染色體の事のみにとがめ詳細は別の機會 に被り度いと思ふ。

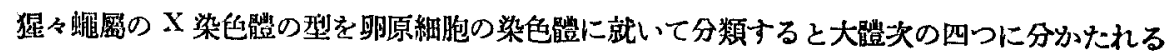
(第 1 圖)。即ち棒狀のもの, 非常に長い椿狀のもの, 大型の $\mathrm{V}$ 及び大型の $\mathrm{V}$ と短い棒狀の組合 つた複合 X (DOBZHANSKY '35)である。此の中特に興味の有るのは大型V 染色體で, 之を睡腺染 せ體に就いて分類寸ると更に三つの型が見出される(第 2 圖)。郎ち V 染色體の片腕の見えぬ

* Katayama, H. and H. Kikkawa, The composition of the Sex Chromosomes in the Genus Drosophili (A Preliminary Note). 